\title{
СЕРБИЯ И СЕРБЫ НАКАНУНЕ БАЛКАНСКИХ ВОЙН ГЛАЗАМИ РУССКИХ (К ДИСКУССИИ О «СОВРЕМЕННОМ» ГОСУДАРСТВЕ)
}

«Война будет популярна и бестрепетна к жертвам»

(Никола Пашич)

«Вся Сербия была мастерской для воспитания народа в едином духе. Каждый солдат с малых лет знал о Прилепе и Скопье, Косовском бое и героях, боровшихся на просторах старой сербской державы.

Он страстно верил в то, что столетиями передавалось из поколения в поколение, - однажды Косово должно быть отмщено!»

(Станое Станоевич)

«Все селяки, грамотные и неграмотные, на память знают свои героические былины; и славные имена сербской истории, действительно, могут считаться народным достоянием.

Я искренне желал бы, чтобы наш русский крестьянин стал, наконец, знаком с историей Владимира Мономаха, Дмитрия Донского или Ивана Грозного, хотя бы наполовину так хорошо, как знакомы сербские селяки со своими историческими преданиями» (Евгений Львович Марков)

Подзаголовочные данные: В статье автор вступает в дискуссию с сербскими историками, считающими, что после смены династий в 1903 г. в Сербии произошел «переход элитарного тира национализма в массовый», что стало основой национального подъема и единения накануне Балканских войн. При этом «массовый национализм», как известно, является категорией современного (modern) общества. Однако, имея в виду традиционную структуру сербского социума, специфику менталитета и особенности политической культуры населения и элит, автор делает вывод, что национальный консенсус вызревал в Сербии на чисто традиционных, патриархальных (а отнюдь не современных) основах.

Ключевые слова: Балканские войны, модернизация, менталитет сербского общества, политическая культура, национальный консенсус, Никола Пашич, русские путешественники 
В отечественной историографии имеется суждение, будто «Балканские войны и их историческая значимость изучены наукой». ${ }^{1}$ На наш взгляд, согласиться с таким тезисом никак невозможно...

История Балканских войн 1912-1913 гг. до сих пор не написана, ${ }^{2}$ ибо они сразу же оказались в историографическом плену Великой войны 19141918 гг. Это обстоятельство создает лакуну в изучении одного из важнейших периодов в истории балканских народов. Балканские войны завершили не только «долгий» XIX век, но и переходную (во многом - переломную) эпоху в развитии всех государств региона. Их военные и геополитические итоги известны, однако они требуют научного осмысления, каковое (в свою очередь) вряд ли станет плодотворным без обращения к внутренним реалиям: традиционной социальной структуре; особенностям менталитета и уровню политической культуры населения и элит; взаимоотношениям власти и общества, их реакции на вызовы предвоенного и военного времени. Иными словами, без рассмотрения степени «модерности» балканских государств и обществ. Ответа требуют вопросы - в чем состоит разгадка «массового национализма» на Балканах, как войны отразились на национальной консолидации балканских народов, с чем в сфере «модернизации» сознания они подошли к кануну Новейшего времени.

Данные вопросы, применительно к Сербии и сербам, мы предполагаем рассмотреть ниже, привлекая в качестве основных источников свидетельства русских наблюдателей, в первую очередь, - дипломатов и военных корреспондентов (среди последних находились писатели и инженеры, активные и отставные офицеры, профессиональные журналисты и общественные деятели)*. 0 непреходящей ценности подобных свидетельств для изучения социокультурной истории Сербии на разных этапах ее развития уже писалось не раз. ${ }^{3}$

$$
* * *
$$

Известно, что объявление мобилизации вызвало в Сербии общее ликование. ${ }^{4}$ «Все три призыва мобилизованы, - писал очевидец событий, - начинается радость и взаимные приветствия; невозможно замыслить, что речь идет об отправке на фронт, где кладутся жизни, а не на сватовство ${ }^{* *}{ }^{5}$ Русский

* Данные военных корреспондентов особо важны для нас, ибо, как справедливо заметил российский журналист Н.И. Гасфельд, «бытописатели юго-славянских земель, наблюдавшие сербов из вагон-салона и изучавшие их по рассказам и со слов сербских политических деятелей, лишены возможности видеть и слышать сербов в серенькие будни, когда они не надевают париков и ненакладывают грима...» (Шевалье Н.(nсевдоним). Правда о войне на Балканах. Записки военного корреспондента. СПб., 1913. С. 97-98).

** Этот мотив «свадьбы» при объявлении мобилизации звучал и в русских СМИ: «Запасные стекались на призывные участки как на свадьбу!» (Родина. 7 октября 1912 г. № 41. С. 1. Приведено по: Гусев Н. С. Тема славянского единства в русской периодической печати во время Балканских войн 1912-1913 гг. // Историки-слависты МГУ. Кн. 8. Славянский мир: в поисках идентичности. М., 2011. С. 464-465). 
глаз также подметил сей факт: «На станциях было много резервистов. Настроение у всех бодрое, а, главное, - совершенно спокойное, будто они ехали на самое обычное дело. И провожающие родственники также не обнаруживали никаких внешних проявлений горя в виде плача, криков и причитаний».

Как докладывал позднее инженер И.П. Табурно, «в течение трех дней явилось 95 \% призывных, через неделю их было 98 \%, лишь 2 \% оказались больными, но и из этих многие явились, прося их взять, в надежде поправиться в дороге». И далее: «Вы думаете, что слышен был плач матерей, жен, сестер, отправляющих своих близких на возможную смерть... Нет, если какая-нибудь баба и проливала тихо невольные слезы, ее сейчас же останавливали, пристыжая: „Как не стыдно плакать - такое святое дело“. Устыженная отвечала: „Я не плачу, что жалею, а плачу от умиления, что с такой радостью идут все освобождать наших братьев; плачу от того, что дождалась это увидеть“».7

«Люди были так воодушевлены, - вспоминал секретарь русской Миссии в Белграде В.Н. Штрандтман, - что бросали работу, чтобы сразу же явиться на сборный пункт. Мне известен случай, когда работавший в частном доме серб не закончил чистку сапог, узнав о призыве его возраста в войска; он бросился опрометью к хозяину, наспех попрощался, не взял причитавшихся ему денег и бегом отправился в местную комендатуру». Не он один - «в других случаях кучера оставляли экипажи и лошадей на дороге, дабы поспеть на место призыва. Кухарки тоже бросали все и спешили уехать в деревню, чтобы заменить мужчин на работе». Словом, «воодушевление было неописуемое», ${ }^{8}$ порой приводившее к казусам, - под впечатлением оного, «старый майор Ковачевич, участник войны 1876 г., покончил с собой из-за сознания, что физическая немощь не позволяет ему принять участие в войне».9

«Война, которую желали все!», - назвал вторжение в Турцию современный сербский историк. ${ }^{10}$ Понятное дело, она ведь «была самой популярной в истории Сербии», - вторит ему соотечественница. ${ }^{11}$

$$
* * *
$$

Пытаясь объяснить данный феномен, сербские исследователи утверждают, что после смены династий (1903) в Королевстве произошел «переход элитарного типа национализма в массовый». ${ }^{12}$ Аргументацию своему заключению они черпают в том, что, на основании «демократической» конституции 1903 г. и избирательного права, большинство мужского населения получило возможность активно участвовать «в элементарной политике», - а это является одним из двух необходимых условий для «эволюции национального движения в сторону массовости». Второе условие: грамотность как минимум трети населения. Причем указывается, что «в реальной 
жизни читать умело более трети сербских граждан, а потому “читательская революция”, как то условие названо в литературе, в Сербии после 1903 г. имела место».

И в итоге, «современный («modern»-A. Ш.) человек, вдохновленный национальной идеей, воспринимает подобную эволюцию как участие в жизни суверенного государства, которое зависит и от него. Он больше не является пассивным наблюдателем». ${ }^{13}$

Мы уже говорили, что объяснять «необыкновенную популярность» войны у сербов, прибегая к категориям и значениям современного общества (а «массовый национализм» к ним, несомненно, относится) не совсем корректно. Разгадку ее, по нашему мнению, надо искать в стереотипах традиционного мышления. ${ }^{14}$ Однако, специфика жанра той работы (обобщающий труд) не позволила нам «развернуть» данный тезис ${ }^{15}$ - ниже это и будет сделано...

Что касается массового участия мужского населения «в элементарной политике», то в ряде работ мы попытались показать чисто традиционное «качество» такого участия, как, впрочем, и самой политики. ${ }^{16}$ Принято даже считать, пишет К. В. Никифоров, что «жизнь в традиционном обществе вообще не знает политики в современном смысле этого слова». ${ }^{17}$ И ведь точно - не знает!

По оценке русского дипломата В. В. Муравьева-Апостола-Коробьина, данной спустя два месяца после Майского переворота, «исчезли в мгновенье ока Обреновичи, воцарился быстро и по всем правилам конституции Карагеогриевич, но сербы остались все теми же. Одна ночь, хотя бы и столь значительная, не смогла их переродить. Уснули на время страсти, встрепенулись некоторые чистые надежды и патриотические благие порывы. Однако для осуществления последних требуется время, ... тогда как для пробуждения природных инстинктов, зависти и ревности, оказался вполне достаточным и протекший двухмесячный срок». ${ }^{18}$ А Б. Н. Евреинов чуть позже дополнил коллегу: «Партийная борьба делается все непримиримее и несдержаннее, переходя все границы такта и приличия. Она охватывает все слои общества, прежде к ней непричастные, и возрастающие под ее пагубным влиянием поколения, неизбежно будут все более и более усиливать и обострять ее до тех пор, пока не настанет тот, могущий оказаться спасительным, кризис», ${ }^{19}$ или же, говоря иначе, «встряска, которая заставила бы здешних политических деятелей отказаться от преследования своих личных и партийных, корыстолюбивых и властолюбивых целей и обратиться к единодушной деятельности в пользу своего отечества». ${ }^{2 *}$

* Российские военные еще более откровенны: «Внутренний быт подвержен разъедающему влиянию политических партий». И значит, «для сплочения сербов нужна популярная, имеющая целью осуществление заветных пожеланий народа, война» (Из секретной «Записки» Главного штаба. Петербург, 10 ноября 1902 г. // Потапов H. M. Русский военный агент в Черногории. Т. І. Донесения, рапорты, телеграммы, письма. 1902-1915. М. - Подгорица, 2003. С. 37). 
Словно в воду глядел: Боснийский кризис 1908 г. консолидировал сербскую элиту, что и проявилось столь успешно во время Балканских войн. «Сербы за свое возрождение должны быть благодарны Австрии, графу Эренталю», - констатировал И. П. Табурно. ${ }^{21}$ И он же далее о войне: «Дисциплина образцовая. Селяне, начальники департаментов, судьи, адвокаты, инженеры, прислуга, рабочие одинаково и пунктуально исполняют приказания старших - беспрекословно и даже охотно, как бы тяжело не было. Безропотно переносят всякие лишения. Куда исчезла критика мирного времени? Как будто ее и не было...» ${ }^{22}$ Но стоило наступить миру, как былые политические язвы вновь обнажились. ${ }^{23}$ По-военному прямолинейный генерал Панта Драшкич назвал вещи своими именами: «Лишь только для нас, сербов, проходит опасность, мы тотчас перегрызаемся между собой». ${ }^{24^{*}} Э$ то одна из констант сербской «политики», весьма характерная и для периода 1903-1914 гг., - якобы «золотого века сербской демократии и парламентаризма», ${ }^{25}$ что (как не раз отмечалось) является явной натяжкой ${ }^{26}$ или «самым устойчивым историческим мифом». ${ }^{27}$

Сей тезис о «золотом веке» проистекает из слишком буквального следования чисто институциональному подходу, который (кроме формальной фиксации наличия в Сербии тех или иных институтов) мало что объясняет по сути. Неоднократно упоминалось, что, при относительно корректном соблюдении парламентской формы в указанный период, политическое содержание институтов парламентаризма и их функционирование заметно отступали от базовых принципов (да и самой природы) классического парламентарного государства. ${ }^{28}$ Причина очевидна: и в эпоху «золотого века» сербский социум сохранял аграрно-патриархальный характер - с почти 90-процентным крестьянским населением; в нем практически отсутствовал средний класс, главный людской ресурс любого прогресса. И, следовательно, начало парламентской практики в Сербии предшествовало становлению в ней «гражданского общества», что шло вразрез с опытом Европы, где все происходило наоборот - там именно гражданин стоял в центре политики. А значит - «парламентская форма» и содержание расходились весьма ощутимо. Поэтому ясно, и здесь мы солидарны с учеными-политологами в том, что «один лишь институциональный анализ не способен объяснить, почему одинаковые по форме институты государственной власти в различных странах порой действуют совершенно по-разному». ${ }^{29}$ И, соответственно, что уже давным давно сформулировал Л. Д. Троцкий, записавший в 1912-1913 гг. на основе увиденного: «Парламентаризм и демократия имеют в Сербии крайне прими-

\footnotetext{
* Н Н избежала такой особенности и сама армия. Полковник Мирко Милосавлевич говорил Слободану Йовановичу: «Пока идут военные операции, мы действуем совместно, как братья; но стоит им прекратиться, словно какой-то дьявол вселяется в нас...» (Цит. по: Јовановић $C$. Апис и сукоб између војних и грађанских власти у Македонији // Сабрана дела С. Јовановића. Т. ХІ. Из историје и књижевности. І. Београд, 1991. С. 338-339).
} 
тивный характер». ${ }^{30}$ И еще, он же, - «На странах Ближнего Востока можно во всех областях жизни проследить, как готовые европейские формы, идеи, иногда только имена заимствуются для того, чтобы дать выражение потребностям более отсталой эпохи. Политический и идейный маскарад есть удел всех запоздалых народов». ${ }^{31}$ Как видим, за вербально-европейским «фасадом» в мышлении сербских политиков часто скрывались традиционные навыки и подходы.

Их происхождение не менее понятно - когда общественная дисциплина, да и весь политический процесс, базируются на личностных (в рамках патриархальной местечковой лояльности), а не формальных (порождаемых индустриализацией) принципах, то чувство долга к своему ближайшему кругу - родственников, земляков, друзей, - как того требовал старый обычай, проявляется у его участников значительно сильнее, чем общегражданская ответственность, закрепленная законом. Соответственно, «другой» в их глазах представал не как представитель своего сообщества, думающий по-иному, но как чужак, отношение к которому было негативным... Что ж! Как заметил все в том же 1912 г. Йован Жуйович академик и министр, «даже у интеллигенции не всегда присутствуют основные понятия о государственой организации». ${ }^{32}$ А четверть столетия ранее Никола Крстич констатировал сей факт еще более определенно: «В Сербии нет интеллигенции, независимой и созревшей для парламентской жизни, - той, которая существует в Европе...».

Касательно же высказанной мысли о «зависимости» жизни Сербии после 1903 г. от «сознательной» деятельности ее гражданина (именуемого, помнится, уже «современным человеком»), приведем иллюстрацию этой довольно неожиданной в «запоздалой стране» ${ }^{*}$ особенности политического процесса.

В одной неподписанной сербской рукописи 1914 г. автор охарактеризовал оную в виде чеканной формулы: «Партизанский дух есть отличие нашей расы. И я сомневаюсь, что когда-нибудь политические страсти обретут у нас более мягкие формы. Партизанство - это наша культура, оно питает наш дух. А сектантство и интриганство - составные части нашей политической морали. Ни одна сербская партия в своей борьбе не руководствуется принципами, заложеными в ее программе, личные интересы доминируют в политической жизни». ${ }^{33}$ При этом, как водится, все сопровождается призывами к народу - «вот только простой селяк из Черной Травы очень бы удивился, узнав, что острая борьба ведется ради него. Он так и помрет, не оценив столь глубоко осознанных народных интересов». ${ }^{34}$

А данный селяк, как известно, давно связал себя с Радикальной партией, ведомой Николой Пашичем (этим, по выражению Троцкого, «аб-

* Выражение Л. Д. Троцкого из его статьи в «Киевской мысли» от 18 ноября 1912 г. (см.: Станчев М., Чернявский Г. Л. Д. Троцкий, Болгария и болгары. София, 2008. С. 66-67). 
солютным властителем Сербии»), причем так прочно, что даже в самые тяжелые для него минуты фаталистически замечал: «Зна Баја, шта ради!», и значит - все образуется... «В Белграде, - продолжал будущий «соавтор» российского Октября, - все политические разговоры вертятся вокруг личности Пашича... Про короля Петра вспоминают только в исключительных случаях, да и то по чисто внешним поводам. А Пашич всегда у всех и на уме и на языке. Он думает за всех, он знает, что нужно». ${ }^{35}$

В традиционном обществе отношения вождя и массы строятся на базе харизмы. Очевидно, что Пашичу удалось добиться этой харизматической степени доверия народа: не зря он более 20 раз возглавлял правительство, а в самые сложные, военные, годы (1912-1918) - бессменно. При этом, как вспоминал Г. Н. Трубецкой, «он так олицетворял свою Сербию, как ни один государственный человек в Европе не олицетворял своей страны». ${ }^{36}$ Отец родной - да и только! Но где же здесь «сознательная деятельность гражданина»?

Как видим, обратная связь между «верхами» и «низами» в Сербии действительно имелась, но, правда, иной природы, чем в государстве, где современный человек осознанно участвует в политике. Соответственно национальное согласие в Королевстве вызревало после 1903 г. на основе традиционно-патриархальных понятий о власти и ее носителях, о чем уже приходилось писать. ${ }^{37}$

Теперь обратимся к вопросу о грамотности. Официально накануне Балканских войн в Сербии было чуть более 30 \% грамотных. ${ }^{38}$ Так, по крайней мере, утверждает статистика, из чего, как мы наблюдали, исследователи подчас делают далеко идущие выводы. Нас, однако, это число совсем не убеждает. И сомневаться в том заставил П. А. Ровинский, рассуждавший о сербской школе еще в конце 60-х гг. XIX в.

Приведем наглядный пример такой «осознанной» обратной связи. «Один мой приятель, - писал на рубеже столетий британский путешественник Герберт Вивиан,присутствовавший на великом радикальном митинге в Белграде в 1896 г., рассказывал мне, что из четырнадцати тысяч участников лишь три или четыре десятка слушали ораторов, остальные же ели дыни (по другим данным, - арбузы, чьи корки потом неделями валялись по белградским улицам. - A. Ш.). Он также добавил, что каждый из них получил по три динара... И вообще, радикалы могут рассчитывать на крестьян в любой момент. В удовольствии совершить экскурсию за партийный счет, те, по первому зову, соберутся где-угодно и проголосуют за любую резолюцию, которую предложат их вожди» (Вивијан Х. Сербија - рај сиромашних. Београд, 2010. С. 62). Или еще: «У радикалов сознательные партийцы - только их лидеры, остальная масса идет за ними, слепо им доверяя» (Тодоровић П. Како је у Србији (последњи извештај покојном краљу Александру) // Исти. Огледало. Зраке из прошлости. Приредила Л. Перовић. Београд, 1997. С. 892). 
С одной стороны, он отдает должное властям в развитии школьного дела: «Нельзя не признать, что Сербия сделала значительные успехи», причем, «опередив числом школ Россию».39 Имеется в виду, на душу населения. Но, с другой, ситуация выглядела не столь благостно - «зная, какими она располагала средствами, и сколько тратится на все, нельзя не потребовать больше того, что сделано». И даже, «не требуя многого, можно требовать, чтоб в том, что делается, были толк и польза, а мы этого-то последнего и не находим...» ${ }^{40}$ И, правда, школ немало, но они «содержатся весьма бедно, и ни один порядочный учитель не идет в них». ${ }^{41}$

В результате, как формулировали сербские власти свою сверхзадачу, «грамотность распространяется, а дальнейшее потом». Мы - государство маленькое, молодое, и «дело идет так, чтоб нельзя было сказать, что ничего не делается». ${ }^{42}$ «Чего вы хотите от нас? Мы недавние, слава Богу, что и это имеем ${ }^{43}$ - рефреном звучит в передаче Ровинского логика сербов.

Как видим, в условиях, когда государство не поощряло прогресса в школьном деле (в частности, не связывало получение образования с обретением каких-либо конкретных преимуществ), оно развивалось формально, для внешнего потребления: самостоятельному de facto Княжеству пристало иметь институт школы... П. А. Ровинский первым разглядел это несоответствие между формой и сутью, буквально возопив (на фоне быстрого-то роста числа школ): «Где же оно, истинное образование» ${ }^{44}$ и поставив под сомнение все значение официальной сербской статистики об успехах страны в данной сфере - «Какое после этого неверное понятие вы составите о Сербии по тем отчетам, которые всякий раз читают перед скупщиной». ${ }^{45}$ Вот где начало нашего неверия в статистику! Которое провоцирует следующий вопрос.

Распространялась ли в реальности эта самая грамотность в народной, и особенно сельской, среде, и откуда тогда замеченное Ровинским и принципиально важное: «Учат, учат в школе, а дети все-таки читать не могут»? ${ }^{46}$ В последнем и содержится негативный ответ, ибо в аграрной, патриархальной Сербии мотивация для получения образования еще не созрела. Традиционный образ жизни предполагал, что большинство детей проследует по ней путем родителей, наследуя их занятия и обычаи. Для чего «домашнее воспитание» («присмотр за скотиной» и т.д.) было куда важнее полученного на стороне абстрактного знания. В свое время мать Еврема Груича - одного из зачинателей либерального движения в Сербии - так пыталась отговорить мужа от идеи отдать его в школу: «Оставь его. Твои родители тоже не знали грамоты и ничего, жили неплохо». ${ }^{47}$ Все точно: «Зафиксированная и аккумулированная в бесписьменной народной культуре, хранимая в живой памяти и передаваемая механизмами неукоснительных традиций, ограниченная совокупность знаний и навыков вполне обеспечивала хозяйственный процесс». ${ }^{48}$ И следовательно, как с 
полным правом заключает Александра Вулетич, «представления о значении просвещения у большинства крестьян были весьма туманными». ${ }^{49}$

Но это относится к концу 1860-х гг. И, быть может, через полвека, в интересующие нас годы, все поменялось: школа из праздной институции превратилась-таки в рассадник реального знания, а «читательская революция» в Сербии совершилась? Понаблюдаем...

В 1882 г. министр просвещения Стоян Новакович выпустил закон об обязательном обучении «каждого ребенка, живущего в Сербии». По своим целям (в патриархальной-то стране) закон был чересчур амбициозен, почему и предусматривал некоторый переходный период. Сроком его окончательного применения определялся 1890 год. И что ж мы видим в этом году? Количество охваченных школой детей не дотянуло и до половины всех, кто достиг школьного возраста; число грамотных вообще составило чуть более $14 \%$. Десять лет спустя количество грамотных достигло $21 \%,{ }^{50}$ а накануне Балканских войн, как уже говорилось, едва перевалило за 30 \%. И это при том, что закон об обязательном начальном образовании (в редакциях 1897 и 1904 гг.) действовал постоянно. В чем же тут дело?

Думается, что, наряду с рядом объективных обстоятельств (нехваткой школьных зданий, учителей), главную причину медленного роста уровня грамотности в независимой Сербии следует искать все в том же отношении самого сербского селяка к просвещению - насколько знание являлось для него жизненной ценностью и внутренней потребностью?

Снова прибегнем к помощи российских авторов. Фиксируя формальную сторону («число первоначальных школ в Сербии в последнее время начинает увеличиваться»), они обращали пристальное внимание на суть дела: «При обучении в первоначальных школах правительство мало соображается с нуждами народа, с его нравами и условиями жизни. Сербский народ вовсе не против просвещения, но в своих школах он не находит того, что требует. Детей не обучают ни рукоделиям, ни ремеслам; мало того, родители замечают, что их дети, окончив курс в первоначальной школе, очень часто отказываются от простой работы. Серб, будучи по природе человеком в высшей степени практическим, находит излишним посылать в школы своих детей, которые в школьный возраст нужны ему для присмотра за скотиной и для всевозможных услут в хозяйстве. Хотя обучение в этой стране обязательно и бесплатно, но сербские поселяне всеми правдами и неправдами стараются удерживать своих детей дома, и вследствие этого много сербов остается безграмотными». ${ }^{51}$

Ну, а для тех, кто все же заканчивал школу, полученное знание действительно было во многом абстрактным, поскольку «мало соображалось с нуждами народа, с его нравами и условиями жизни» и, соответственно, - никак не применялось на практике. Как таковое (невостребованное), оно не являлось первой повседневной необходимостью, что, в свою очередь, не могло не вли- 
ять на судьбу номинально грамотных людей. Речь здесь идет о типическом для всех традиционных обществ феномене «вторичной неграмотности».52

Проиллюстрируем данную мысль фрагментом записок одного из редких ученых сербов - по должности окружного врача. «Нет лучшего школьного ревизора, - писал он на исходе XIX в., - чем окружной или срезский (уездный. - А. Ш.) врач, так как у него есть возможность при призыве в армию видеть тех детей, которые десять лет назад посещали школу. В селе, где школа существует тридцать лет, и где почти все прошли через нее, при призыве в армию оказалось, что из 40 бывших учеников только двое умеют читать и писать; 15 человек не умеют писать, но кое-как читают, а остальные и не читают, и не пишут. В том, что эти дети, по окончании школы, уходят в горы пасти скот и никогда больше не берут книгу в руки, виноваты не учителя. Просто у нас никто не желал об этом думать - ни одно правительство не предложило лекарства от болезни. И какой смысл в том, что такие большие деньги тратятся на учителей и школы, если в действительности народ не имеет от них ни малейшей пользы, ибо те, кто после сельской школы решает продолжить занятия, идут в чиновники, священники или становятся сельскими писарями - остальные дети забывают все...». И далее звучит уже знакомый мотив: «Крестьяне бы и хотели иметь школу в каждом селе, но при том условии, чтобы власть не требовала от них, что она должна быть по единому плану».53

Полтора десятилетия спустя (1908 г.) члены Шумадийского учительского общества, опрашивая в окрестностях Крагуевца крестьянскую молодежь, 10 лет назад окончившую первоначальную школу, были вынуждены констатировать, что «у огромного большинства парней и девушек исчезло почти все полученное в школе знание, а многие из них вообще разучились и читать, и писать! Большинство из них за время, прошедшее после школы, не написало ни единого слова и ничего не прочло!» ${ }^{54}$ Но уже то, что «они были в состоянии, мучительно и обливаясь потом, вывести свой автограф, - подчеркивает Момчило Исич, - относило их к категории грамотных». ${ }^{55}$ Таковы были критерии.

Важно отметить, что указанный феномен «вторичной неграмотности» отличался в Сербии стабильностью - между поездкой Ровинского и подготовкой отчета Учительского общества прошло ровно сорок лет. А следовательно, и в самом сербском социуме к началу Балканских войн мало что изменилось по существу - в сравнении с уже довольно далеким прошлым.

В своей недавно вышедшей монографии бельгийский исследователь Мишель Паларе пришел практически к тем же выводам: «Власти открывали школы все больше и чаще, но при этом мало прислушивались к тому, что действительно надобно крестьянам. И многие из них (хотя формально и образованные) оставались функционально неграмотными*, а те, кто имел пользу от

Тот же термин - «функциональная неграмотность» - употребляет и немецкий исследователь Хольм Зюндхаузен (см.: Зундхаузен Х. Историја Србије од 19. до 21. века. Београд, 2009. С. 190). 
образования, считали его лишь средством бегства из деревни... Школа выглядела негативно в глазах крестьянина, который полагал, что получившие образование дети будут потеряны для его хозяйства». ${ }^{56}$

Причем негативно настолько, что в 1905 (!) г. депутаты Народной скупщины с села без сожаления ввели налог на торговлю учебниками, однако не решились на ту же меру в отношении выгонки домашней ракии. ${ }^{57}$ Или еще пример - накануне Мировой войны (!!!) в Мачве, самом плодородном и богатом крае Сербии, было 32 школьных здания, из которых лишь 5-7 соответствовало своему назначению. Современник констатировал: «В Мачве и еще некоторых краях крестьяне начинают массово строить вполне современные конюшни для правильного выращивания лошадей и другого скота; детей же оставляют во влажных, тесных, и во всех отношениях убогих хибарах, которые зовутся начальными школами». ${ }^{58}$ Иерархия ценностей налицо!

Итак, несмотря на общее число закончивших школу (весьма, кстати, и невеликое), реально грамотных людей в Сербии было много меньше, что наглядно подтверждает всю относительность формальной стороны (статистики!). Как и в случае с парламентаризмом, между de-jure и de-facto в школьном деле образовался «зазор» ${ }^{*}$ - абстрактное знание со временем выветривалось, не получая возможности адекватного применения в жизни, ибо традиционное общество не поощряло новаций, - «предшествующее» в нем «становилось нормой для последующего». ${ }^{59}$

И, следовательно (повторим этот системный для патриархальной Сербии принцип), одна только голая форма, в частности, - принятие законов об обязательном образованиии, наличие почти что в каждом селе школы и т.д., автоматически не являлась свидетельством успешной модернизации. Нема-

Такой «зазор» имел системный характер, распространяясь на все «новые» надстроечные элементы и порождаясь «старым» типом базиса. Покажем сей факт и на примере сербского здравоохранения. В 1876 г. русский врач-доброволец писал: «В каждом из 17-ти округов Княжества существовала небольшая больница, но жители неохотно обращались туда за помощью, так что те больницы пользовались скорее официальным, чем действительным значением» (Коломнин C. Общий медицинский очерк Сербскотурецкой войны 1876 г. и тыла армии в Бессарабии и Румынии во время Турецкой войны 1877 г. // Русские о Сербии и сербах. СПб., 2006. С. 251). Прошло два десятилетия, но они мало что изменили: «Бывали случаи, что во время эпидемий правительство посылало врачей в селения, но к ним никто не обращался...» (Овсяный Н. Р. Сербия и сербы. СПб., 1898. С. 162.). Или же :«Ориент начинается к югу от Будапешта. Здесь в первый раз, если следовать от Гамбурга, хозяева поколотили тех, кого власть послала дезинфецировать их жилье после смерти холерного больного» (Димитријевић Л. Како живи наш народ. Београд, 2010. С. 62). А больницы-то были, но «сделала ли хоть что-нибудь для народа государственная медицинская служба, кроме содержания окружных больниц, ставших в провинции настоящей божьей благодатью для бездомных?» (Там же. С. 47). Негативный ответ очевиден... Итак, даже на рубеже веков крестьяне больниц не посещали, ибо, по словам русского очевидца (1897 г.) «они в болезнях и не лечатся», считая, что «их посылают какие-то неведомые враждебные силы», - поэтому «селяк и прибегает к ворожеям и знахаркам, полагая, что они в состоянии тем же самым способом, каким напущены на него болезни, и прогнать их - при помощи волшебства, колдовства, чар и т.д.» (Отдел рукописей Российской Национальной библиотеки. Ф. 1179. Д. 92. Л. 6). 
лые по меркам Сербии вложения в просвещение, которых в конечном итоге все равно не хватало, часто прокручивались вхолостую; соответственно и результаты крайне амбициозных школьных реформ были весьма скромны. Очевидно, что сербские власти не преуспели к Балканским войнам и в обычном-то «ликбезе», не говоря уж о создании условий для «читательской революции».

\section{$* * *$}

И еще несколько суждений, касательно природы и качества грамотности в Сербии, на сей раз - с привлечением элементов «компаративности».

Для «затравки» - процитируем болгарского историка Наума Кайчева: «Несмотря на крупный исторический гандикап, сербская государственная машина в начале 1880-х была вынуждена решать те же задачи, что вплотную встали и перед болгарским государством-младенцем, - создание регулярной армии, национального банка, современной судебной системы. Не на последнем месте в списке реформ стояли введение всеобего начального образования и организация целостной системы просвещения». ${ }^{60}$ При этом (что важно для нашей темы), процент грамотных после проведения школьной реформы, число учеников и объем госвложений в образование на душу населения, были в Болгарии много выше, чем в Сербии, ${ }^{61}$ - ведь еще в середине 80-х гг,, после принятия амбициозного закона о всеобщем начальном образовании, сербское правительство в расчете на одного жителя вкладывало в школьное дело всего-то 0,63 динара, тогда как Хорватия и Славония, к примеру, - 1,35; а Восточная Румелия (под османским суверенитетом!) - вообще 2,48 динаров. ${ }^{62}$

Еще 25 июля 1878 г., на заседании Совета российского комиссара в Болгарии, М. С. Дринов докладывал, что в ней «существует два вида училищ: начальные и так называемые главные. Первые из них, т.е. начальные училища, находятся почти в каждом селении, за исключением губерний Софийской и Видинской, где их сравнительно менее. Главные же - почти во всех городах и местечках Придунайской Болгарии. В главных училищах дается общее образование, и они обыкновенно состоят из четырех классов, кроме габровского, в котором уже имеется семь классов». ${ }^{63}$ И следом - принципиальнейшее замечание: «До сего времени все вообще училища в Болгарии носили название народных и устраивались и содержались исключительно населением, с живым интересом относившимся к народному образованию».64

Последнее наглядно иллюстрирует отрывок из послания генерала Э. И. Тотлебена (весьма удивленного виденным во время путешествия по Болгарии и Восточной Румелии весной 1879 г.) императору Александру II: «Особого внимания заслуживают устройство и распространение народных школ. Не только в городах, но и в каждой деревне выходили ко мне мальчики и девушки с их учителями и учительницами». И далее - «Преподавание весьма простое и практичное, обучение детей обязательно для всех. В крае, какой столько лет находился под гнетом мусульман, подобное явление не- 
вольно возбуждает удивление», при том, что «в Габрове и Казанлыке существовали до войны институты для образования учительниц». ${ }^{65}$

Но почему же, спрашивается, практически независимое государство так уступало в реальных результатах «колониальным» странам, в первую очередь - Болгарии?

Нам представляется убедительной высказанная Мишелем Паларе мысль о том, что болгарская элита под крышей турок не была инкорпорирована в политическую и военную надстройку государства. Ей оставалась ниша «бизнеса», для чего оказалось необходимым подлинное знание. При этом, - в ходе складывания единого османского рынка развивалась хозяйственная специализация регионов, в рамках которой нашлось место и для Болгарии («болгарский экономический ренессанс»), что опять-таки требовало грамотности. Причем программы образования были привязаны к реальным потребностям (вспомним Тотлебена: «Преподавание весьма простое и практичное»), ибо само оно «санкционировалось» снизу, в отличие от Сербии, где «государство приспособило всю образовательную систему своим собственным надобностям: для рекрутации чиновников, поставив содержательный акцент на национальных ценностях, - в ущерб привитию практических навыков».66*

* $\quad$ Упомянутый англичанин записал свои впечатления от посещения провинциальной школы: «Совсем маленькиемальчикичиталипатриотические стихи своодушевлением игордостью. Когда же учитель вывел ученика к карте балканских стран, то я пожелал услышать, что он знаетоБоснии,итутжеполучил ответ-Босниюнаселяют сербы, но,кнесчастью,внастоящий момент она томится под властью австрийцев. Кроме православных сербов, в ней живут и сербы-мусульмане, которые большие патриоты из-за своего сербского происхождения» (Вивијан Х. Сербија - рај сиромашних. С. 208)... В Болгарии все было иначе. Поскольку у болгар было мало возможностей для самореализации на государственной службе, упомянутый «ренессанс» (кроме «бизнесменов») создал и «национально фрустрированную интеллигенцию», обуреваемую, вплоть до паранойи, националистическими мечтами. Так, в Габрово (и это наглядно иллюстрирует их «столкновение») шла многолетняя борьба между «реформистскими» учителями и главами городского самоуправления, в ходе которой реформисты хотели освободить школьные программы и планы от «языка торговцев», дабы вознести националистические ценности выше той цели, ради которой, собственно, школы и создавались: сохранения и приумножения материальной культуры. А так как ситуация на османском рынке - и институциональные перемены в Империи весьма способствовали «болгарскому экономическому ренессансу», то политическое негодование «патриотической» части интеллигенции (которая сама-то являлась продуктом «ренессанса») не смогли объединить болгар против оттоманского режима (См.: Паларе М. Балканске привреде око 1800-1914. Еволуција без развоја. Београд, 2010. С. 197). Наум Кайчев также подчеркивает, что «иерархия ценностй» в болгарских учебниках отличалась от таковой же у сербов: «Военные ценности не доминируют в учебниках. В них редко встречаются стихи, величающие в глазах маленьких читателей смерть за Родину. Гораздо чаще описываются добродетели просвещения, культуры, грамотности (Кирилл и Мефодий, Климент Охридский), как и красоты родной земли» (Кайчев Н. Македонийо, възжелана. Армията, училището и градежът на нация в Сърбия и България (1878-1912). София, 2006. С. 92). Неслучайно, говоря о фазе строительства Болгарского княжества, Диана Мишкова отмечает пассивность народа, «невозможность вызвать его энтузиазм». И даже в 1911 г., по наблюдению Р. П. Гришиной, «политическое единение, необходимое для страны, намеревающейся вступить в войну, отсутствовало...» (Гришина Р. П. Болгария на пути к войне и Болгарский земледельческий народный союз // Славянский мир в эпоху войн и конфликтов XX в. СПб, 2011. С. 14, 22). Перевод сознания болгар на военные рельсы был сделан позднее, «искусственным» путем. Чем все закончилось, - известно! 
Потому-то к началу XX в. в числе грамотных сельских обывателей, болгар и сербов, и «зиял» такой разрыв - 28,4* и $12 \% ; 67$ к тому же грамотность (подчеркнем) в болгарском варианте была, в основном, «активной».68 Так что, Болгария, как нам думается, имела все шансы эволюционировать по пути естественной модернизации: ментальные предпосылки для этого в народе складывались. Недаром, отличный знаток Балкан, генерал Н. Р. Овсяный указывал: «Что касается настойчивости в достижении целей, трудолюбия и бережливости, серб много уступает своему соседу - болгарину». ${ }^{9}$ Не менее квалифицированный эксперт, британец Генри Блейсфорд, тоже утверждал, что у сербов «отсутствует способность к постоянной работе, потому-то они и достигли за восемьдесят лет меньшего морального и материального прогресса, чем болгары всего за двадцать пять...» ${ }^{70}$ Да и некоторые сербы отдавали себе в этом отчет. «Народ трудолюбив, повсюду видны обработанные и полные плодов нивы, на которых в разгар страды старательно копошатся селяки», - зафиксировал в дневнике, на пути из Белграда в Константинополь, сербский журналист Пера Тодорович. Причем, «даже работая в поле, они хорошо одеты; приятно видеть их белые, будто снег, рубашки». ${ }^{71}$ Словом, как отметил еще в ходе болгарского Освобождения в письме супруге едва оглядевшийся русский воин, «деревни благоденствуют, жатва снимается...» ${ }^{72}$

Перед нами, таким образом, - очередной аргумент в пользу того, что, уж если вести разговор о «читательской революции» на Балканах в начале XX в., то гораздо корректнее делать это применительно к Болгарии, нежели к Сербии.

В сербской историографии подчеркивается, что «при переходе в стадию массового национализма главным и самым эффективным оружием становится печатный станок». И далее: «Накануне Мировой войны сербский народ имел весьма развитую периодическую печать», ${ }^{73}$ что являлось очередным свидетельством успешности все той же «читательской революции». И впрямь, по словам Л. Д. Троцкого, «Война застала в Белграде четырнадцать ежедневных газет - это на город с населением немногим более 80 тысяч душ... Благодаря развитой политической жизни, пресса играет здесь огромную роль. Она явилась одним из решающих факторов, создавших психологические предпосылки войны (имеется в виду - I Балканской. - А. Ш.)». ${ }^{74}$

Но, приглядевшись, Лев Давидович дал хлесткую характеристику ее природы: «С 1903 г. здесь политическим полем почти полностью владе-

В селах Тырновского округа, жители которого специализировались в садоводстве и огородничестве для продажи, грамотных было 43,3 \% (Паларе М. Балканске привреде око 1800-1914. Еволуција без развоја. С. 372). Показательно, но даже те «овощи, которые потребляются в Белграде, возделываются болгарами на другом берегу Савы и каждое утро привозятся из Землина...» (Лавелэ де Э. Балканский полуостров. Ч. 2. М., 1889. С. 12). 
ет Радикальная партия». Однако она «не имеет в своих руках прессы». Поэтому «с 1903 г. в сербской политике все резче вырабатывается противоречие между официально-радикальным курсом и прессой». Далее - «Прессой руководит молодое поколение, которое не проделало революционной борьбы с Обреновичами, но успело разочароваться в ее результатах... Создался слой городской полуинтеллигенции, которая мало чему училась, не имеет за собой идейных заслуг, но проникнута уверенностью, что будущее Сербии принадлежит ей*. Эти деклассированные элементы, стоящие на границе люмпенства и, во всяком случае, проникнутые духовным люмпенством насквозь, безраздельно владеют сербской прессой», чья «оппозиционность - есть лишь другая сторона ее жадного цинизма». И, наконец: «Бездарная, малограмотная, низменная сербская пресса вносит гниение в идейную жизнь страны и является самым зловредным фактором сербской общественности». ${ }^{75}$

Показательно, но и сербский суверен высказал о данном предмете весьма схожую мысль. 5 апреля 1905 г. российский посланник в Белграде К. А. Губастов сообщал в МИД об аудиенции у короля Петра: «Его Величество откровенно заметил, что ему пришлось во многом разочароваться относительно сербских деятелей. Судя их издали, он не думал, что они были так деморализованы, поверхностны и легкомысленны. Причины этого он видит отчасти в самом характере сербов, но, главным образом, в печати, коя имеет на общество и на народ развращающее влияние. „У нас нет, - сказал с горечью король, - ни серьезных писателей, ни честных газет. Все они изощряются лишь в ежедневной брани друг с другом и живут скандалами“». ${ }^{76}$

Крайне точное суждение: острое внутреннее противостояние (та самая «константа» сербской политики) традиционно выплескивалось на страницы печати, причем в жесткой форме. Что, впрочем, уже давно нико-

Эти рассуждения Л. Д. Троцкого о сербской «полуинтеллигенции» полностью легитимны, что лишь подчеркивает глубину его проникновения в сербские (балканские) реалии. Классик сербской исторической науки Слободан Йованович называл данный тип людей «полуинтеллектуалами», которые «хотя и завершили школу, не обрели никакого культурного образования и морального воспитания». По причине ли врожденной неспособности, либо недостатков школьной системы, полуинтеллектуал «не получил никакого импульса для духовного саморазвития. Он не разумеет значения духовных ценностей, уважая лишь то, что способствует успеху в жизни, а сам успех воспринимает совсем по-мещански - в смысле сугубо материальном... Диплом об образовании, как пропуск в круг интеллигенции, дал ему преувеличенно высокое мнение о себе самом. В общественном соревновании такой примитивец с дипломом бьется без всяких правил, с полным уверением, что тем самым он обеспечивает свое право. Соперников он убирает с пути немилосердно: так, словно те - не живые люди, а обычные физические препятствия». Его «политическая амбиция - на самом деле, совсем не политическая. Она состоит только в том, чтобы, войдя в политику, обогатиться и покомандовать с высоких постов. Он совсем не представляет, что могут быть какие-то высшие и общие цели...» (Јовановић C. Један прилог за проучавање српског националног карактера // Сабрана дела С. Јовановића. Т. XII. Из историје и књижевности. II. Београд, 1991. С. 571-572). 
го не удивляло. Так, в 1881 г., в момент образования политических партий, прибывшему из Вены в Белград для редактирования партийного органа напредняков («прогрессистов») Тодору Стефановичу-Виловскому Пера Тодорович посоветовал «писать не „в перчатках“, но так, как публика в Сербии привыкла». ${ }^{77}$ А год спустя, в ответ на вопрос П. А. Кулаковского о том, что пишут сербские писатели, король Милан Обренович ответил: «Сербские писатели пишут по газетам ругательного свойства статьи». ${ }^{78}$ В последнем русский профессор и сам сумел убедиться совсем скоро. «Следует заметить, - сообщал он Н. А. Попову, - что общий вывод изо всей сербской журналистики теперь тот, что здесь нет теперь ни авторитета, ни почтения к лицу какому бы то ни было, нет никакой идеи, никакого морального правила, какое бы руководило жизнью общества. Грустная картина разрушения!» ${ }^{79}$

Не изменилась такая практика и далее. В 1892 г. газета «Отпор» («Сопротивление») назвала Николу Пашича (в это время уже премьера!) «лжецом, клеветником и изменником родины», закончив столь привычным для сербской политической практики призывом: «На виселицу Пашича». ${ }^{8 * *}$ А накануне выборов 1905 г. Коста Кумануди писал Милану Ракичу, как орган независимых радикалов («самостальцев») «Одьек» («Эхо») и старорадикальная «Самоуправа» («Самоуправление»), «с кровавой пеной у рта бросают друг другу одни и те же оскорбления и самые жуткие обвинения, из коих наиболее мягкое - „предательство“ и „служба интересам Австрии“». ${ }^{81}$ Схожих примеров можно привести немало.

Жесткость характеристик (особенно в «национальном» контексте) можно понять - многовековое противостояние с Османской империей привело к формированию у сербов конфронтационного сознания, и это во многом определяло специфику внутренней жизни. В условиях незавершенности процесса всесербского «освобождения и объединения» (что оставалось для большинства «сербиянской» элиты задачей первейшей; в том числе после появления в 1878 г. на границе Княжества Австро-Венгрии - нового врага, «сменившего» турок и водворившегося в Боснии и Герцеговине), оно органично экстраполировалось и на отношение к «другому» внутри страны. Соответственно, мир для ее граждан (не важно внешний ли, внутренний) был по-прежнему окрашен в черно-белые тона. Оттого в диалоге политических сил столь часто и присутствуют взаимные упреки в «измене родине».

Это внешнее «воздействие», заметим к слову, есть второй важный фактор (наряду с «местечковой» лояльностью), объясняющий высокую степень политического антагонизма в Сербии.

\footnotetext{
* Традиция эта не угасла и в период «золотого века». Прибывший из России Н. И. Гасфельд заметил, что нередко мишенью для газетного обстрела «являются министры, стоящие у власти, которых обвиняют в уголовном прошлом и государственной измене, и предлагают заменить немедленно своими ставленниками» (Шевалье Н. Правда о войне на Балканах... С. 98-99).
} 
Владан Джорджевич (премьер в 1897-1900 гг.) впоследствии писал: «Тяжела была судьба ответственных политиков в семидесятые, восьмидесятые и девяностые годы XIX в. Страна тогда раздиралась борьбой вошедших в кровавый клинч нескольких партий; при этом каждая из них полагала, что она-то и есть хранительница сербского патриотизма». ${ }^{82}$ После переворота 1903 г. число «хранителей» возросло - с претензией на патриотическую монополию выступили офицеры-заговорщики, основавшие в 1911 г. тайную организацию «Объединение или смерть» (другое ее название «Черная рука»), с собственным печатным органом - газетой «Пьемонт».83 Да и радикалы, как мы видели, окончательно раскололись, поделив свой былой «монополизм» пополам. Все это привело к еще большему «накалу» в столичных СМИ.

Разочаровавшись в принципах «парламентского» государства, не дававших, как они полагали, возможности скорого решения сербского национального вопроса, и видя в них лишь источник перманентных межпартийных склок, лидеры «Черной руки» выступали с позиций централизма, милитаризма и национализма, становясь (чем дальше - тем больше) угрозой гражданскому правлению. «Пьемонт» в первом же по счету номере от 3 сентября 1911 г.) «привычно» обвинил все партии «в аморализме, бескультурье и непатриотизме». Единственным лекарством объявлялся «централизм», с опорой на армию. ${ }^{84}$ Особо жесткие филиппики доставались от газеты правящим старорадикалам и их лидеру Николе Пашичу. Что опять же понятно, - слишком уж по-разному (при единстве стратегического курса на освобождение и объединение сербов) смотрели военные и гражданские на тактические и функциональные задачи власти.

Психологию такого антагонизма описал видный сербский социо- и этно-психолог Владимир Дворникович: «Борьба лишь обостряется, когда речь идет о разнице в понятиях близкого (родственного) порядка. Психология фанатичного борца требует определеную и эксклюзивную цель. Она должна быть предельно просто сформулирована, иметь характер догмы и не допускать никаких комплексов, никаких полутонов и переходных нюансов; никакой конкуренции родственных идей, которые, быть может, направлены к той же цели, но подразумевают иной темп, иные методы и иные формулы. Именно в отношении самых близких нюансов, границы и противоположности намеренно углубляются... Гражданские войны между партиями, принадлежащими к одной нации и государству, - более страшны, чем войны между разными государствами и народами*». ${ }^{85}$ Боян Йованович назвал данное явление «нарциссизмом малых различий»:86 «Нарциссоидное настояние на различиях есть показатель недовольства

П. А. Кулаковский еще в 1882 г. констатировал - «Меня больно поражало всегда в Сербии... то, что здесь партии ненавидят друг друга больше, чем общего врага...» (Рукописное отделение Института русской литературы РАН. Ф. 572. Д. 44. Л. 27 об. (П. А. Кулаковский - И. С. Аксакову. Белград, 3 марта 1882 г.)). 
„качеством“ совместной идентичности, в той же мере, насколько она не достигнута и на более низком уровне общности (выделено нами. - А. Ш.)». ${ }^{87}$ Круг замкнулся...

Из наших кратких размышлений о белградской (но совсем не сербской! - очевидно ведь, что не «сербский народ» имел «весьма развитую печать»*) периодике и ее манерах следует несколько заключений.

Во-первых. Она оставалась, по выражению Сюзаны Раич, настоящим «полем боя» ${ }^{88}$ различных политических сил, причем непосвященному читателю могло показаться, что на нем «ведется война против иностранных завоевателей». ${ }^{89}$ «Сопровождая» и ретранслируя партийную борьбу, которая, как помним, становилась «все непримиримее и несдержаннее, переходя все границы такта и приличия» (и это не случайно), пресса следовала в том же традиционном русле, переводя государственное и общее на уровень личного. «Когда вы читаете передовицы тех газет, и особенно партийных, - заключает Дубравка Стоянович, - то складывается впечатление, что их главная цель - оскорбить противника, высмеять его, подвергнуть поруганию. Так, словно нет никаких ограничений того, что можно говорить». И далее: «Возникает вопрос, был ли данный тип печати индикатором демократизации общества, или, напротив, таким способом создавалась анархоидное политическое пространство, в котором возможно все, ... где не действуют никакие правила и принципы? При таком понимании свободы печати создается стиль, когда личные оскорбления напрочь вытесняют дискуссии о политических вопросах, а политика сводится к сшибкам главных участников». И, следовательно, «общий и государственный интерес заменяются выяснениями личных отношений». В результате, «все важное отходит в сторону, а общество лишается возможности четко артикулировать перспективы своего развития...» ${ }^{90}$

Во-вторых. «Сербиянская» элита (за исключением, возможно, редких напредняков - сторонников гражданской опции) всегда была настроена патриотически. Национальная сатисфакция оставалась для нее святой и «наследственной» целью. В 1895 г. специальная комиссия, в которую вошли представители академического сообщества, давала названия белградским улицам: огромное большинство новых топонимов было связано с географией (городами, горами, реками) предполагаемой «Великой Сербии», кроме одного - Москва. ${ }^{91}$ Равно и программы в школах, военно-учебных заведениях и т.д. были соответствующим образом сориентированны.

Весной 1883 г., в момент первого всплеска «газетной войны» в Сербии, Милан Миличевич записал в дневнике: «Когда человек читает, что газеты пишут о Сербии, но при этом сам в ней не находится, он может подумать, что здесь за малым не вспыхнул порох. А когда видит, что происходит в народе, он должен скорее смеяться, чем удивляться бессовестности газет и всех этих газетных недовольных» (Архив Српске академије наука и уметности. Бр. 9327. Дневник М. Милићевића. Књ. 11 (запись от 16 апреля 1883 г.)). 
Так, в Белградской унтер-офицерской школе, по свидетельству русского военного туриста, среди прочих предметов, преподавали «историю и географию Великой Сербии от моря до моря (!? - А. Ш.)».92

И, в-третьих. «Читательская революция» произошла к началу Балканских войн не в Сербии, а в Белграде, - что подтверждается процентом грамотных столичных жителей ${ }^{*}$ и количеством газет; основанием в 1905 г. Университета (в числе его студентов было даже 14 девиц) ${ }^{93}$ и наличием как европейски образованной бюрократии, так и отдельных, там же признанных, ученых (И. Панчич, Й. Жуйович, Й. Цвийич, Дж. Даничич, Ст. Новакович)...

Однако, Белград, напрямую граничивший с Европой через Саву, представлял собой островок культуры и модерности ${ }^{94}$ в море не желавшей отступать патриархальности. И 14 студенток Университета не должны вводить в заблуждение, заслоняя главное, - остальные женщины были практически исключены из сферы образования ${ }^{* *}$; общий же его уровень в Сербии оставался катастрофическим. ${ }^{95}$ Влияние столицы на окружающий руральный мир, таким образом, было минимальным - сербский селяк буквально «в штыки» воспринимал город и городскую культуру. Русские очевидец фиксировал, что «пастухи и земледельцы, сербы не видят необходимости селиться в городах». ${ }^{96}$ И далее: «Крестьянин, убежденный селяк, поразительно равнодушен к городу. Он кончает свои сделки на окраине, запивает могарычи в ее душных кафанах и, со спокойным духом, возвращается восвояси, в глушь деревни, потерянной между гор и лесов».97 Соответственно, не терпел он и вмешательства горожан: «Селяки буянят на сходках: не хотим людей в пальто!», - писал один белградец в 1905 г. ${ }^{98} \mathrm{~A} \mathrm{pa-}$ дикальный официоз «Самоуправа» вообще призывал: «Село и крестьянин еще сохраняют сербскую народную мысль, и им необходимо уничтожить влияние города - этого гнезда иноземщины». ${ }^{99}$

Примечательно, но столь же «антигородской» настрой сохранили и внуки крестьян, маршировавших в 1912 г. по «Европейской Турции». Добрица Чосич, описывая земляков из своего села Великая Дренова уже в титовские и посттитовские годы, запечатлел одного, что «любил старые дома и сельскую старину, не перенося на дух ничто городское, кроме стиральной машины, которую считал самым выдающимся изобретением $\mathrm{XX}$ в., ибо она освободила женщину от унизительного труда». ${ }^{100}$ Другой,

* В 1900 г. в Белграде было всего 27 \% неграмотных; в то время как на селе $88 \%$ населения не умело ни читать, ни писать (Зундхаузен Х. Историја Србије од 19. до 21. века. С. 188)... Однако, и здесь не все так однозначно. Сохранились данные о количестве книг, прочитанных жителями столицы в 1903-1908 гг. И что мы видим? В 1903 г. сто белградцев прочли 16 книг; в 1906 - 22; а в 1908 - 15 (Ђуровић А. Модернизација образовања у Краљевини Србији. 1905-1914. Београд, 2004. С. 109). Несколько странная для «читательской революции» динамика.

** В начале XX в. только 9 \% замужних женщин могли написать свои имя и фамилию (Зундхаузен Х. Историја Србије од 19. до 21. века. С. 188). 
«не то, чтобы ненавидел город, однако никогда не согласился бы в нем жить». ${ }^{101}$ Даже интеллигент (известный философ и литературовед Сретен Марич), родом из села Субела в Ужицких горах, «любил все старое, сербское, невозвратно исчезавшее, и презирал выскочек и порочную балканскую черту - буквально очаровываться чужим, „современным“ европейством...» ${ }^{102}$ А Латинка Перович вспоминает, какие призывы слышались в сербской глубинке во время местных выборов в конце 60-х: «Голосуйте за него, он - наш, он носит гунь (крестьянскую куртку из грубого сукна. - А. Ш.). За учителя же не голосуйте, - кто знает, куда он нас заведет». ${ }^{103}$ Сословная мужицкая ментальность, как видим, несмотря на все попытки коммунистов вытравить ее, так и не поддалась...

Сравнивая Белград, с его образованными жителями (к каким вполне может подойти понятие - массовый национализм), и «остальную» (крестьянскую и неграмотную) Сербию, Слободан Йованович в одном послевоенном письме высказал мысль, которая заслуживает глубокого осмысления: «Перед войной я совсем уж было потерял веру в наше будущее, но сейчас мне кажется, что мы... оказались тогда слишком большими пессимистами. Белград - не Сербия; это то, чего не следует забывать, - мы ошибались, когда по тому, что видели в столице, делали вывод, что точно так же происходит и во всей стране». ${ }^{104^{*}}$

$$
* * *
$$

А как, собственно, «происходило во всей стране»? Какие механизмы (если это - не школа) обусловили всеобщий подъем накануне Балканских войн?

Пытаясь объяснить данный «феномен», Миле Белаяц замечает: «нам весьма близка мысль о том, что основы сербского национального сознания закладывались в последней четверти XIX в. домашним патриархальным воспитанием крестьянского света, когда мать, которая всегда рядом, формирует у детей первые взгляды на мир, сами же дети ... долгими вечерами в тысячный раз распевают народный эпос». ${ }^{105}$

Должно сказать, что мы также разделяем эту мысль и ниже постараемся показать ее справедливость...

Уже неоднократно упоминалось, что сербское аграрное общество в своем «бытии» всецело опиралось на традицию, воспринимая в качестве источника всякой деятельности прошлое. ${ }^{106}$ Иллюстрации ради, приведем

На рубеже столетий Герберт Вивиан проницательно заметил: «Все сербы - пламенные патриоты... И нет большего заблуждения, чем полагать, что готовность к войне характерная черта одних лишь высших классов» (Вивијан X. Сербија - рај сиромашних. C. 90). 
фрагмент из мемуаров Милана Стоядиновича о выступлениях знаменитого оратора, члена ЦК Радикальной партии, ужицкого священника Милана Джурича. «Главным его аргументом, - писал премьер межвоенной Югославии, - была апелляция к „прадедовским костям“. Обычно он провозглашал: “Прадедовские кости требуют от нас". Или: “Кости прадедов взывают к нам из могил”. Такой патриотический настрой его речей всегда имел большой успех». ${ }^{107^{*}}$ Его так и называли - «прадедовские кости». ${ }^{108}$ В 1913 г., после сербских побед в Балканской войне, поп Милан собрал в Ужице огромный митинг, на котором заявил: «Братья! Косово отмщено, отмщены прадедовские кости, мы снова видим блеск Душановой короны!»109 Данный пример подтверждают всю оправданность тезиса, что одной из базовых традиционалистских установок являлась идея преемственности - т.е. «солидарности поколения живущего с поколениями умершими», ${ }^{110}$ или «участия минувших поколений в современности». ${ }^{111}$

Особо наглядно это «участие минувших поколений в современности» проявлялось в подходе родителей к воспитанию, когда (в передаче П. А. Ровинского) отцы заставляют своих чад «выучивать в виде катехизиса историю падения сербского царства на Косовом поле, причем делают такие выводы, что Милошу Обиличу - на вечные времена слава, Вуку Бранковичу - проклятие, а турку и швабу нужно посечь головы...» ${ }^{112} \mathrm{C}$ течением времени в данной системе воспитания мало что изменилось. Спустя почти полвека после путешествия Ровинского, другой русский автор констатировал: «Когда старый дед учит внука владеть саблей или кинжалом, тогда жилище серба наполняется избытком высокого наслаждения и удовольствия. Преемствено, от поколения к поколению, передаются имена освободителей народа от турецкого ига, и в честь их слагаются песни». ${ }^{113}$

Образованные сербы, признавая явный перекос «героического» воспитания, тем не менее так объясняли его необходимость: «Видите, в каком мы положении: мы должны из наших детей готовить вместо гуманных граждан - диких солдат, потому что нам грозит война с турками, борьба с варварами, с которыми нужно мериться тем же оружием, каким они пользуются против нас». ${ }^{114}$ Сей мотив грядущей войны и необходимости подготовки к ней с самого «нежного» возраста тиражировался на всех уровнях. Прота Милан Джурич с парламентской трибуны требовал от учителей так воспитывать детей, «чтобы они знали заветную мысль (об освобождении и объединении сербства. - А. Ш.), знали о косовских героях, ... и в будущем, став гражданами, отомстили бы за Косово и создали Великую Сербию». Или другой его пассаж: «Мать пасет овец или жнет ячмень и пшеницу, но при этом поет сыну песню и готовит его к отмщению Косова». ${ }^{115}$ А автор знаменитых «Десяти дней, которые потрясли мир» Джон Рид отписывал о сербах: «Каждый солдат из крестьян знает, за что он сражается. Еще когда он был маленьким ребенком, мать приветствовала его: „Здравствуй, маленький мститель за Косово“...»116 Отметим этот эсхатологический мотив - мать за- 
ранее готова к возможной гибели своего ребенка! Что оставляло сильное впечатление на европеек. Швейцарская медсестра Катарина Штурценегер зафиксировала в дневнике: «Как это просто, естественно, но и глубоко... С патриотизмом сербских дам мир должен считаться! Вместо того, чтобы советовать своим супругам, отцам, братьям и друзьям уклониться от вооруженной защиты нации, или страстной рекой слез задерживать расставание, они, напротив, его ускоряют: долг в отношении нации у них на первом месте - в сравнении с собственным сердцем». ${ }^{117}$

Итак, юнацкое (т.е. героическое) начало закладывалось в сербских детей с младых ногтей. Не только в школе, как мы уже наблюдали, но (что значительно важнее) вне ее - известный сербский историк Панта Сречкович вспоминал: «Хозяин трактира, у которого я столовался, был хорошим человеком и всегда рассказывал о Прилепе и королевиче Марко. Хозяин лучше учителя знал, где находился дворец Марко, где были Душановы палаты, где Вукашиновы, и как Вукашин убил Уроша... Про эти детали Чира (учитель. - А. Ш.) нам не говорил». ${ }^{118^{*}}$ Оно не могло не сказаться на формировании детского мироощущения, какое всегда оставалось сугубо конфронтационным в рамках оппозиции «свой - чужой». И даже когда чужие менялись (то есть, когда к туркам добавились «соседи» из-за Савы и Дуная), отношение к ним оставалось столь же жестко-одномерным. В «Катехизисе для сербского народа» читаем: «Кто неприятель сербов? - Самый главный враг сербов - Австрия... Что надобно делать? - Ненавидеть Австрию, как своего самого главного врага... А кто друг сербов и Сербии? - Единственный искренний и надежный друг сербов, который был и есть: великая и мощная Россия. - В чем долг каждого серба? - Любить свое отечество и монарха и умирать за них, уважать своих друзей и ненавидеть врагов...» ${ }^{119}$

Данный подход проявляет себя особенно контрастно в сравнении с другим типом мышления. Иллюстрации ради, приведем разговор Владана Джорджевича (воспитанного в Европе и отнюдь не фанатикарадикала, вроде проты Джурича) с чешским национальным деятелем Ладиславом Ф. Ригером. На реплику Ригера, что «австрийское ярмо ста-

* Известный российский педагог Е. Л. Марков, путешествовавший в 1895 г. по Сербии, оставил яркое свидетельство о встрече с сербскими крестьянами в одной придорожной механе (трактире): «Когда разговор зашел о Косовом побоище, то все заговорили разом и так горячо, что ничего понять было нельзя; но хозяин мианы сердито крикнул чтото и к нашему столику выдвинул высокого молодого парня. „Вот он лучше всех может рассказать про Косову битву!“, - кричали кругом. „Пусть он рассказывает“. Я подумал, что малый, вероятно, не очень давно учился в школе и почерпнул уже из книг свои сведения о великом побоище. Но оказалось, что он неграмотен, в школе никогда не был, а одарен необыкновенной памятью и знает наизусть все, что когда-нибудь читали и рассказывали ему. Действительно, он удивил нас подробным и складным рассказом обо всех подробностях Косовского погрома, об убиении Мурада, об измене Вука, о смерти царя Лазаря» (Марков E. Путешествие по Сербии и Черногории. Путевые очерки // Русские о Сербии и сербах. Т. І. СПб., 2006. С. 310). 
новится для чешского народа слишком тяжелым», собеседник задал ему естественный для всякого серба вопрос: «Почему же тогда чешский народ не сбросит его?». На что им был получен характерный ответ - «Народ, у которого почти в каждом втором доме стоит пианино, не поднимает революций». ${ }^{120}$ Перед нами два наглядных проявления двух систем мышления, названных Ю. М. Лотманом бинарной и тернарной. Вторая «стремится приспособить идеал к реальности», тогда как первая - «осуществить на практике неосуществимый идеал», ${ }^{121}$ в случае с сербами: реализовать мегаломанскую мечту - восстановить свою средневековую державу, т.е. Душаново царство*. В 1880 г. П. А. Кулаковский делился с Ап. А. Майковым: “Царство Душана не дает сербам спать”, - недавно гдето я читал, и это правда: не было бы вредно, если б этим историческим славным воспоминанием сербы поддерживали свой дух, но беда в том, что это историческое воспоминание заставляет их разыгрывать роль, им не подходящую, заставляет их обманывать и нас, и себя; заставляет их больше мечтать и меньше делать». ${ }^{122}$

Прошли десятилетия, но в системе мышления одних и других опять же ничего не изменилось. В начале рокового 1914 г. оказавшийся в сербской столице русский турист писал: «Белград делает сейчас заем в 40 миллионов франков, из которых 20 миллионов предназначено на постройку общественных зданий. Многие находят, что для Белграда это расход чрезмерный», утверждая, «что украшать город хорошо, ... но, что пушки, пожалуй, надежнее. Не лучше ли иметь лишних 20 скорострельных пушек, чем построить один дом?». В ответ на это, гость вспомнил о своей встрече с мэром Праги, «когда он показывал народный банк, который обошелся чуть ли не в четыре миллиона франков. Я спросил, как может маленькая Чехия возводить такие дворцы, которые считались бы роскошью даже в России или во Франции. Он ответил, что положение России и Чехии несравнимо, чешский крестьянин знает, что он окружен со всех сторон немцами, которые хотят задавить его самосознание, ему тяжело, его надо подбодрить. Вот и строятся дворцы для обслуживания народных нужд, чтобы показать народу его силу и мощь его единения. Каждая такая постройка есть новая крепость, она придает крестьянину веру в самого себя, в свои силы и укрепляет его дух...» ${ }^{123}$

Кстати, о фортепиано. В 1898 г. (спустя двадцать лет после диалога Джорджевича и Ригера) в старой сербской столице Крагуеваце имелось одно-единственное (!!!) пианино, принадлежавшее переселенцам из Срема. ${ }^{124}$ Музыкальные запросы сербов из Королевства были иными: героические песни, исполняемые на гуслях, помогали им усиливать

Легитимность данного заключения вполне подтверждается выводом национальной историографии: «Обновление царства Душана являлось идеалом для многих сербских националистов XIX в.» (Макуљевић Н. Уметност и национална идеја у XIX веку. Београд, 2006. C. 85). 
участие минувших поколений в современности. П. А. Ровинский описал финал исполнения одной из таких песен - «А когда дело дошло до Вука Бранковича, что выдал царя на Косове, и пропел ему певец: “Проклят будь и род его и племя!” - “Проклят!”, крикнули тут все и повскочили с мест, как будто бы ища изменника, предавшего сербство...» ${ }^{125}$ И много лет спустя, на пороге XX в., эстетические пристрастия «сербиянцев» не менялись: «Поставили скамейку, посадили гусляра, и он начал напевать весьма немелодичным речитативом, однообразно попиливая лучком по единственной струне, старинные народные песни все о тех же царях и битвах, поминая и Косово поле, и Призрен, и Приштину, и Митровицу, все исторические местности своей незабвенной „Сербии под Турском“». И, как заключение: «Сколько я (Е. Л. Марков. - А. Ш.) не слышал потом песен в Сербии, всегда темы их были одни и те же - воспоминания о старых битвах, о старых народных героях». ${ }^{126}$

А пианино, в основном, и далее оставалось принадлежностью «иностранцев». Лаза Димитриевич - окружной врач, в своих (недавно переизданных) записках с юмором писал о том, что смогло бы изменить его карьеру: «Закончив медицинский факультет, я получил должность окружного доктора в Крагуеваце. Тогда еще не было железной дороги, и мне, как женатому человеку, переселение на воловьих повозках доставило бы массу проблем. Особенно пианино, которое моя жена (вывезенная из Вены, где он учился. - А. Ш.) ни за что не желала бросать. С того момента я этот инструмент возненавидел. Однако, назавтра оказалось, что и в Смедерево есть свободное место, и я подумал - пианино, корабль, город на берегу. Все планы поменялись... Так что, не будь пианино, был бы я окружным врачом в Крагуеваце, и вся моя жизнь потекла бы по другому руслу». ${ }^{127}$ Вот так!

В. Н. Штрандтман вспоминал, как накануне Балканских войн сербы ему «говорили, что они живут изо дня в день под страхом набегов соседей. Когда я их спрашивал, почему их столица так невыгодно с внешней стороны отличается от столицы Болгарии, они мне отвечали, что не имеет смысла отстраивать большие дома, потому что рано или поздно они подвергнутся вражескому разрушению». ${ }^{128}$ Отмотаем пленку на полвека назад. И что мы обнаруживаем? То, что Ровинский и тогда наблюдал идентичное: Сербия «производит впечатление какого-то полувоенного лагеря» - все в ней «временное, неустановившееся, все в каком-то ожидании чего-то»; вся «она живет накануне, вся в каком-то воинственном настроении», стоя «вечно на карауле».129 
Этот исторически и географически зыбкий экзистенциальный фундамент сербского дома породил особый образ существования его обитателей - частую смену защитных (или наступательных) действий и передышек: с новым ожиданием, терпением, собиранием сил. Соответственно, сербы Княжества (Королевства) практически и не жили, постоянно воюя, либо готовясь к войне, находясь в никогда не спадавшем психологическом напряжении*: в 1876-1918 гг. страна пережила шесть военных конфликтов. В таких условиях, как писал Владимир Дворникович, «в нашем народе создался какой-то специфический ритм и темп жизни, слабо приспособленный к современным методам труда и созидания». ${ }^{130}$ Понятное дело: вместо естественного поступательного развития - всплески отчаянного напряжения и относительно мирные паузы, заполненные не «органичной работой», а ожиданием того, ради чего сербские дети и воспитывались отнюдь не в добродетелях чешских «бюргеров», с их «малыми делами» и пианино в каждом втором доме. ${ }^{131}$

Известный литератор Велько Петрович, накануне I Балканской войны написал, что «Сербия возжелала войну, ибо ее не было больше трех десятилетий. За это время выросли новые поколения, уже не помнившие войны, но только слышавшие о ней от стариков. А в рассказах тех звучали и упреки молодым за недостаток патриотизма и слабость к западной культуре с ее комфортной жизнью без жертв». ${ }^{132}$ Что ж, на эти упреки «новые поколения» и ответили осенью 1912 и летом 1913 гг. Согласно завещанию стариков!..

Таким образом, как мы старались показать, коллективный портрет серба начала XX в. вполне можно было бы подписать - Homo Militans, ${ }^{133}$ или «человек вечной войны», как его называли русские очевидцы. ${ }^{134}$

Явления подобного рода («Humanitas Heroica») свойственны культурам пограничья, каковым издавна были Балканы, формируя у их носителей своеобразный этос поведения и идеалы героизма. Характерными чертами «образцового» защитника собственного этноса и культуры являются те, что объединены «драматизмом мученичества», ${ }^{135}$ когда «отдельная личность» приносится в жертву «всему сообществу».

Здесь, как нам кажется, корни «популярности» войны у сербов, что подтверждает и русский наблюдатель: «Общий народный подъем коренился в целых столетиях пережитой истории, в былинах и песнях, в наглядных политических уроках момента». ${ }^{136}$

Именно поэтому, - когда настала пора решающих столкновений, во имя отмщения Косова, они (словно доказывая мысль В. О. Ключевского,

Л. Д. Троцкий донес до нас определение «балканского мира», данное сербским министром финансов Лазой Пачу: «Балканский мир - это постоянная частичная изнурительная война...» (Троцкий Л. Д. Балканы и Балканская война // Русские о Сербии и сербах. Т. I. C. 507). 
что «цементирующая сила - это традиция и цель» ${ }^{137}$ все, как один*, и ринулись в бой. Да так, что видавшие виды русские дивились: «Здесь узловой пункт. Нет шума, нет пьяных, нет плачущих женщин. Вообще ничего похожего на наши родные картины при отправке на войну запасных...» И в глазах провожающей сына матери «ни единой слезинки». В них только одно - «Напред, сине, с Богом!»138

Как и несколько лет спустя, во время Первой мировой войны, только сербская, как нам кажется, женщина могла написать сыну, оказавшемуся в австрийском плену: «Я все думаю, что, если тебя все-таки пленили, то ты, наверное, был ранен и не мог защищаться. Но, сынок, если ты сдался сам и при этом даже не был ранен, домой не возвращайся. Ты осрамил бы наше село, которое положило на алтарь отечества жизнь восьмидесяти трех героев из ста двадцати, сколько их всего было призвано в армию. Твой брат Милан погиб у Рудника. Должно быть, он был счастлив, когда видел, как его старый король стреляет из первых шеренг...» ${ }^{139^{* *}}$

\footnotetext{
Иэто-неметафораавтора.Патриархальная модельобщества (согласноформуле:сербский народ - сообщество равных) в условиях незавершенности процесса общесербского «освобождения и объединения» становилась средством и формой консолидации сербов Королевства, ибо малая расщепленность интересов внутри социума позволяла сохранять единство народного духа - эту важнейшую внутреннюю предпосылку будущего освобождения. Социальное равенство, как видим, отождествлялось с национальным единением... Объясняя подоплеку всеобщего подъема, захлестнувшего Сербию в начале I Балканской войны, российский наблюдатель писал: «В ряду причин того удивительного объединения, которое приходится наблюдать здесь, следует, разумеется, отметить и сравнительную неразвитость социальных отношений, а, следовательно, и социальных антагонизмов. Личность не успела еще выделиться из коллектива, а экономическое развитие не успело вырыть психологической пропасти между управляющими и управляемыми» (Вольский Ст. Письма с Балкан // Русские о Сербии и сербах. Т. I. С. 538).

** Отцы также не выбивались из традиционного правила. «Бывали случаи - найдет отец сына, а тому в бой идти уже нужно, в цепь становиться, и отец идет с сыном в цепь... Если сын ранен, он счастлив, что находится возле него, выносит его из огня, а если убит, то без слез хоронит, приговаривая: “Он исполнил свой долг, я счастлив, что имел такого сына"» (ОР РНБ. Ф. 1000. Оп. 2. Д. 1348 (Табурно И. П. Доклад о ходе и результатах Балканской войны). С. 61)... А в октябре 1912 г., жена российского посланника в Сербии Н. Г. Гартвига зафиксировала: «Только что хоронили чиновника министерства иностранных дел Ковачевича, тело которого привезли в кусках из-под Куманова. Старик-отец (известный историк Любомир Ковачевич. - А. Ш.) перед прощанием обратился к сыну словами: “Прощай, юнак, ты видишь, я не плачу, ступай с миром к престолу Всевышнего и скажи царям Душану и Лазарю, что Косово поле освобождено". Это был единственный сын старика» (Центральный Исторический архив Москвы. Ф. 179. Оп. 21. Д. 3017. Л. 31; Козлов В. Ф. Москва - Сербии. Из истории русско-сербских связей XVII - начала XX в. М., 2001. С. 51).
} 


\section{Примечания}

(Endnotes)

1 Нюркаева А. З. Балканы во взглядах Л. Д. Троцкого. Пермь, 1994. С. 37.

2 Ситуация начала исправляться только в самое последнее время. См., например: Балкански ратови 1912-1913: нова виђења и тумачења. Београд, 2013.

3 Шемякин А. Л. «Мир детства» сербов в путевых записках П. А. Ровинского // Славянский альманах. 2003. М., 2004. С. 72-93; Он же. Введение // Русские о Сербии и сербах. Т. I. СПб., 2006. С. 5-11; Он же. Специфика политического процесса в независимой Сербии глазами русских очевидцев (1878-1918) // Српске студије. Књ. 1. Београд, 2010. С. 241-263; Он же. Русская профессура о Сербии и сербах (последняя треть XIX в.) // Историки-слависты МГУ. Кн. 8. Славянский мир: в поисках идентичности. М., 2011. С. 346-360. Барби А. Српске победе. Београд, 1913. С. 11-12.

5 Цит. по: Милошевић К. Од савезништва до непријатељства. Србија у Балканским ратовима 1912-1913. Београд, 2007. С. 38.

6 Мартынов Е. И. Сербы в борьбе с царем Фердинандом. Заметки очевидца // Русские о Сербии и сербах. Т. І. С. 556.

7 Отдел рукописей Российской Национальной библиотеки (далее - ОР РНБ). Ф. 1000. Оп. 2. Д. 1348 (Табурно И. П. Доклад о ходе и результатах Балканской войны). С. 9-10.

8 Штрандман В. Балканске успомене. Београд, 2009. С. 195.

9 Вестник Европы. 1913. № 1. С. 353. Приведено по: Гусев Н. С. Тема славянского единства в русской периодической печати во время Балканских войн 19121913 гг. // Историки-слависты МГУ. Кн. 8. ... С. 465.

10 Глигоријевић Б. Краљ Александар Карађорђевић. Т. І. У ратовима за национално ослобођење. Београд, 2002. С. 75.

11 Велмар-Јанковић С. Капија Балкана. Београд, 2011. С. 578.

12 Екмечић М. Дуго кретање између клања и орања. Историја Срба у Новом веку (1492-1992). Београд, 2007. С. 302; Радојевић М. Научник и политика. Политичка биографија Божидара Марковића (1874-1946). Београд, 2007. С. 78; Димић Љ., Радојевић М. Србија у Великом рату 1914-1918. Кратка историја. Београд, 2014. С. 28-31, и др.

13 Екмечић М. Дуго кретање између клања и орања... С. 302-303; 306.

14 Шемякин А. Л. Сербия в начале XX века // Югославия в XX веке. Очерки политической истории. М., 2011. С. 43.

15 Впервые этот тезис был высказан нами на конференции «Славянский мир в глазах России» в 2008 г. Ее материалы опубликованы в конце 2011 г. См.: Шемякин А. Л. Относительность самооценок: сербский крестьянин глазами русских путешественников // Славянский мир в глазах России. М., 2011. С. 177-194.

16 Шемякин А. Л. Обреченная конституция: сербский Устав 1889 г. // Новая и новейшая история. 2002. № 4. С. 64-81; Он же. Традиционное общество и вызовы модернизации. Сербия последней трети XIX - начала XX в. глазами русских // Человек на Балканах и процессы модернизации. Синдром отягощенной наследственности (последняя треть XIX - первая половина 
XX в.). СПб., 2004. С. 10-53; Он же. Народ и власть в независимой Сербии // Двести лет новой сербской государственности. СПб., 2005. С. 176-201. Он же. Политические партии в независимой Сербии (1878-1918) // Человек на Балканах. Государство и его институты: гримасы политической модернизации (последняя четверть XIX - начало XX в.). СПб., 2006. С. 199-214; Он же. Политическая культура в независимой Сербии // Человек на Балканах. Власть и общество: опыт взаимодействия (конец XIX - начало XXв.). СПб., 2009. С. 64-85; Он же. В плену у традиции: русские путешественники о Сербии и сербах (вторая половина XIX - начало XX века) // Политичекая культура и международные отношения в новое и новейшее время. Нижний Новгород, 2009. С. 120-136.

17 Никифоров К. В. Парламентаризм в Сербии в XX веке // Славяноведение. 2004. № 3. C. 8.

18 Архив внешней политики Российской империи (далее - АВПРИ). Ф. Политархив. Оп. 482. Д. 2868. Л. 212 (В. В. Муравьев-Апостол-Коробьин - графу В. Н. Ламздорфу. Белград, 29 мая 1903 г.).

19 Там же. Д. 2869. Л. 67 (Б.Н. Евреинов - графу В. Н. Ламздорфу. Белград, 11 июля 1906 г.).

20 Там же.

21 ОР РНБ. Ф. 1000. Оп. 2. Д. 1348 (Табурно И. П. Доклад о ходе и результатах Балканской войны). С. 13.

22 Там же. С. 15.

23 См.: Вучковић В. Унутрашње кризе у Србији и Први светски рат // Историјски часопис. Књ. XIV-XV. Београд, 1965. С. 173-229; Батаковић Д. Изазови парламентарне демократије - Никола Пашић, радикали и «Црна Рука» // Никола Пашић. Живот и дело (Зборник радова). Београд, 1997. С. 309-329, и др.

24 Драшкић П. Моји мемоари. Приредио Д. Батаковић. Београд, 1990. С. 117.

25 Поповић М. Борбе за парламентарни режим у Србији. Београд, 1939. С. 89; Чубриловић В. Историја политичке мисли у Србији XIX века. Београд, 1982. С. 282-283; Историја Српског народа. Београд. 1983. Књ. 6. Т. 1. С. 92; Екмечић М. Стварање Југославије. Београд. 1989. Књ. 2. С. 546; Живојиновић Д. Краљ Петар I Карађорђевић. Београд, 1990. Књ. 2. С. 115; Протић М. Радикали у Србији. Идеје и покрет (1881-1903). Београд, 1990. С. 17; Љушић Р. Историја српске државности. Књ. 2. Србија и Црна Гора - нововековне српске државе. Нови Сад, 2001. C. 203-204; Bataković D. Storm over Serbia. The Rivalry between Civilian and Military Authorities (1911-1914) // Balcanica. Vol. LXIV. Belgrade, 2013. P. 307-308; и др. ... Данная оценка была популярна и в мировой литературе. См., например: Dragnich A. The Development of Parlamentary Government in Serbia. N.Y., 1978. Р. 106 (в сербском переводе - Драгнић А. Развој парламентаризма у Србији у XIX веку. Београд, 1989. С. 117-118); Балканы в конце XIX - начале $\mathrm{XX}$ века. Очерки становления национальных государств и политической структуры в Юго-Восточной Европе. М., 1990. С. 20-21; и др.

26 Из работ последнего десятилетия, где затрагивается данный сюжет, см.: Стојановић Д. Србија и демократија. 1903-1914. Београд, 2003; С. 348-420; Chrobak T. Srbsko za vlady Petra Karadjordjeviće // Dejiny Srbska. Praha, 2005. S. 249-250; Popović-Obradović O. Mit o začecima parlamentarizma u Srbiji 19031914: «zlatno doba srpske demokratije» // Ista. Kakva ili kolika država. Priredila L. Perović. Beograd, 2008. S. 224-253; Лазић М. Друштвени односи у Србији у време закаснелог капиталистичког развоја // Годишњак за друштвену 
историју. Београд, 2009. Св. 3. С. 24; Шемякин А. Л. Сербия в начале XX века... С. 22-37; Вишняков Я. В. Военный фактор и государственное развитие Сербии начала XX века. М., 2012. С. 255-266; и др.

27 Stojanović D. Steeplechase. Politička kultura kao prepreka modernizaciji Srbije // Ista. Ulje na vodi. Ogledi iz istorije sadašnjosti Srbije. Beograd, 2010. S. 61.

28 См.: Шемякин А. Л. Народ и власть в независимой Сербии...; Он же. Политические партии в независимой Сербии ...; Он же. Политическая культура в независимой Сербии...; Он же. Сербия в начале $\mathrm{XX}$ века...

29 Пугачев В., Соловьев А. Введение в политологию. М., 2004. С. 325.

30 Троцкий Л. Д. Балканы и Балканская война // Русские о Сербии и сербах. Т. І. С. 526.

31 Там же. С. 510.

32 Жујовић Ј. Дневник. Т. І. Приредио Д. Тодоровић. Београд, 1986. С. 226.

33 Архив Српске Академије наука и уметности (далее - АСАНУ). Заоставштина Милана Живановића. Бр. 14434/719 («Конфликт 1914. године»). С. 2-3.

34 Там же. С. 12.

35 Троцкий Л. Д. Балканы и Балканская война... С. 516.

36 Трубецкой Г. Н. Русская дипломатия 1914-1917 гг. и война на Балканах // Русские о Сербии и сербах. Т. І. С. 613.

37 См.: Шемякин А. Л. Народ и власть в независимой Сербии ... С. 191-196.

38 Ђуровић А. Модернизација образовања у Краљевини Србији. 1905-1914. Београд, 2004. С. 63.

39 Ровинский П. А. Белград. Его устройство и общественная жизнь. II // Русские о Сербии и сербах. Т. I. C. 56; Он же. Болгарский хайдук Панайот и его записки // Отечественные записки. 1878. Т. III. Кн. 8. С. 350.

40 Он же. Белград. Его устройство и общественная жизнь. II. ... С. 56.

41 Там же. С. 57.

42 Ровинский П. А. Сербская Морава. Воспоминания из путешествия по Сербии в 1868 г. // Вестник Европы. 1876 г. Т. II. Кн. 4. С. 523.

43 Он же. Белград. Его устройство и общественная жизнь. II. ... С. 56.

44 Там же.

45 Ровинский П. А. Сербская Морава... С. 523.

46 Там же. С. 522.

47 Цит. по: Вулетић А. Породица у Србији средином 19. века. Београд, 2002. С. 82.

48 Кузьмин M. Н. Переход от традиционного общества к гражданскому: изменение человека // Вопросы философии. 1997. №2. С. 60.

49 Вулетић. А. Породица у Србији средином 19. века. С. 82.

50 Трговчевић Љ. Планирана елита. Београд, 2003. С. 27.

51 Водовозова E. Н. Как люди на белом свете живут. Болгары, сербы, черногорцы // Русские о Сербии и сербах. Т. І. С. 371.

52 См.: Православная жизнь русских крестьян XIX-XX веков. М., 2001. С. 330-331.

53 Димитријевић Л. Како живи наш народ. Београд, 2010 (1 изд. - Белград, 1893). C. 46 .

54 Цит. по: Исић М. Писменост у Србији у 19. веку // Образовање код Срба кроз векове. Београд, 2003. С. 78. 
55 Там же.

56 Паларе М. Балканске привреде око 1800-1914. Еволуција без развоја. Београд, 2010. С. 371.

57 Самоуправа (Београд). 28. новембра 1905. г. Приведено по: Паларе М. Балканске привреде око 1800-1914. Еволуција без развоја. С. 372.

58 Цит. по: Исић М. Писменост у Србији у 19. веку... С. 66-67.

59 Гордон А. В. Крестьянство Востока: исторический субъект, культурная традиция, социальная общность. М., 1988. С. 70.

60 Кайчев $H$. Македонийо, възжелана. Армията, училището и градежът на нацията в Сърбия и България (1878-1912). София, 2006. С. 29.

61 Там же. С. 50, 59, 71-72.

62 Зундхаузен Х. Историја Србије од 19. до 21. века. Београд, 2009. С. 187.

63 Освобождение Болгарии от турецкого ига. Документы в 3-х тт. Т. III. М., 1967. C. 180.

64 Там же.

65 Там же. С. 498-499.

66 Паларе М. Балканске привреде око 1800-1914. Еволуција без развоја. С. 203, 370-372.

67 Там же. С. 372.

68 Там же.

69 Овсяный Н. Р. Сербия и сербы // Русские о Сербии и сербах. Т. І. С. 392.

70 Цит. по: Растовић А. Велика Британија и Македонско питање. 1903-1908. године. Београд, 2011. С. 44.

71 Тодоровић П. Дневник. Приредила Л. Перовић. Београд, 1990. С. 189-190.

72 Рукописное отделение Института русской литературы РАН (Пушкинского дома). Ф. 253. Д. 719. Л. 52 (М. Н. Раевский - М. Г. Раевской. Черноводы, 2 августа 1877 г.).

73 Екмечић М. Дуго кретање између клања и орања... С. 306.

74 Троцкий Л. Д. Балканы и Балканская война... С. 523.

75 Там же. С. 523-524.

76 АВПРИ. Ф. Политархив. Д. 2869. Л. 133 об. (К.А. Губастов - графу В. Н. Ламздорфу).

77 Мемоари Т. Стефановића Виловског (1881-1920). Приредио В. Крестић. Нови-Сад, 2010. С. 62.

78 РО ИРЛИ. Ф. 572. Д. 44. Л. 27 (П. А. Кулаковский - И. С. Аксакову. Белград, 3 марта 1882 г.).

79 Научно-исследовательский Отдел рукописей Российской Государственной библиотеки. Ф. 239. Папка 12. Д. 3. Л. 14 (Белград, 4 апреля 1882 г.).

80 Живети у Београду. Документа Управе града Београда. Књ. 6. 1890-1940. Београд, 2008. С. 168-170.

81 Цит. по: Радојевић M. Научник и политика. Политичка биографија Божидара Марковића (1874-1946). С. 115-116.

82 Рукописно одељење Матице Српске (даље - РОМС). Бр. М.14.045. Ђорђевић В. Успомене: културне скице из XIX века. Књ. 3. «У војсци». С. XI. 
83 Батаковић Д. Изазови парламентарне демократије - Никола Пашић, радикали и «Црна Рука»... С. 311.

84 Там же. С. 316-317.

85 Дворниковић В. Национализам и социјализам, или «биолигија идеја» // Исти. Борба идеја. Београд, 1995. С. 130.

86 Јовановић Б. Пркос и инат. Београд, 2008. С. 42.

87 Там же. С. 44.

88 Рајић C. Александар Обреновић. Владар напрелазу векова. Сукобљени светови. Београд, 2011. С. 212.

89 Она же. Владан Ђорђевић. Биографија поузданог обреновићевца. Београд, 2007. С. 182.

90 Стојановић Д. Калдрма и асфалт. Урбанизација и европеизација Београда. 1890-1914. Београд, 2008. С. 251-252.

91 Stojanović D. Steeplechase. Politička kultura kao prepreka modernizaciji Srbije... S. 78-79.

92 Риттих П. А. По Балканам. Путевые впечатления военного туриста // Русские о Сербии и сербах. Т. I. С. 494.

93 Зундхаузен Х. Историја Србије од 19. до 21. века. С. 189.

94 Подробнее о развитии Белграда в начале XX в. см.: Prosić-Dvornić M. Odevanje u Beogradu u XIX i početkom XX veka. Beograd, 2006; Стојановић Д. Калдрма и асфалт. Урбанизација и европеизација Београда. 1890-1914; Мишковић $H$. Базари и булевари. Свет живота у Београду 19. века. Београд, 2010. С. 291-371; Велмар-Јанковић С. Капија Балкана. С. 475-582.

95 Зундхаузен Х. Историја Србије од 19. до 21. века. С. 191.

96 Вейнберг Е. Сербия и сербы. Этнографический очерк // Русские о Сербии и сербах. T. I. С. 473.

97 Амфитеатров А. В. Славянское горе // Русские о Сербии и сербах. Т. І. С. 461.

98 АСАНУ. Бр. 12877.

99 Политички елементи у Србији пре 60. година // Самоуправа. 20. јануар 1941. Бр. 1144.

100 Ћосић Д. Пријатељи мога века. Београд, 2011. С. 334.

101 Там же. С. 337.

102 Там же. С. 388.

103 Lakičević M. Ispred vremena. Beograd, 2011. S. 87.

104 Календарски преглед // Сабрана дела С. Јовановића. Т. XII. Из историје и књижевности. II.Београд, 1991. С. 741.

105 Bjelajac M. Uloga udžbenika u epohama nacionalne integracije XIX i početkom XX veka kod Srba // Bjelajac M., Krivokapić-Jović G. Prilozi iz naučne kritike. Srpska istoriografija i svet. Beograd, 2011. S. 192.

106 См. например: Шемякин А. Л. Сербское общество на рубеже XIX - XX вВ.: традиционализм и модернизация. Взгляд изнутри // Человек на Балканах в эпоху кризисов и этнополитических столкновений. СПб., 2002. С. 31-49; Он же. Традиционное общество и вызовы модернизации. Сербия последней трети XIX - начала XX в. глазами русских...

107 Стојадиновић М. Ни рат, ни пакт. Ријека, 1970. С.11. 
108 Јовановић-Стојимировић М. Прота Ђурић // Он же. Силуете старог Београда. Књ. 2. Београд, 1987. С. 151.

109 Цит. по: Игњић С. Народни трибун прота Милан Ђурић. Ужице, 1992. С. 169.

110 Шацкий Е. Утопия и традиция. М., 1990. С. 230.

111 Манхейм К. Консервативная мысль // Манхейм К. Диагноз нашего времени. M., 1994. C. 610.

112 Ровинский П. А. Сербская Морава... С. 556-557.

113 Кожухов А. Н. Сербия и сербы. Каменец-Подольск, 1915. С. 12.

114 Ровинский П. А. Белград, его устройство и общественная жизнь. II. ... С. 74-75.

115 Цит. по: Поповић-Обрадовић О. Војна елита и цивилна власт у Србији 19031914. године // Србија у модернизацијским процесима 19. и 20. века. Књ. 3. Улога елита. Београд, 2003. С. 204.

116 Рид Д. Вдоль фронта. М. - Л., 1928. С. 66.

117 Цит. по: Мишковић Н. Базари и булевари. Свет живота у Београду 19. века. С. 269-270.

118 Цит. по: Bjelajac M. Uloga udžbenika u epohama nacionalne integracije XIX i početkom XX veka kod Srba... S. 193.

119 Катихизис за народ српски // Златибор. Народни лист. Ужице. 17 априла 1888 г. Бр. 17.

120 РОМС. Бр. М.14.045. Владан Ђорђевић. Успомене: културне скице из XIX века. Књ. 3. «У војсци». С. XXVIII.

121 Лотман Ю. М. Культура и взрыв // Он же. Семиосфера. СПб., 2000. С. 142.

122 ОР РНБ. Ф. 452. Оп. 1. Д. 277. Л. 8-8 об. (Белград, 18 октября 1880 г.).

123 Комаров Г. В. В Белград на Пасху // Русские о Сербии и сербах. Т. I. С. 575.

124 Каниц. Ф. Србија. Земља и становништво. Београд, 1985. Књ. 1. С. 301.

125 Ровинский П. А. Сербская Морава... С. 530.

126 Марков Е. Путешествие по Сербии и Черногории. Путевые очерки // Русские о Сербии и сербах. Т. I. С. 310.

127 Димитријевић Л. Како живи наш народ. С. 99.

128 Штрандман В. Балканске успомене. С. 124.

129 Ровинский П. А. Сербская Морава... С. 557-558.

130 Дворниковић В. Херојски тип и његове негативности // Исти. Борба идеја. С. 111.

131 о специфике «образа существования» чешских «бюргеров» см.: Серапионова E. П. Чешская деревня глазами русских с первой трети XX в. // Славянский мир в глазах России. С. 195-217.

132 Цит. по: Глигоријевић Б. Краљ Александар Карађорђевић. Т. І. ... С. 76.

133 о происхождении данного термина и его первоначальном значении см.: Тананаева Л. И. Сарматский портрет. Из истории польского портрета эпохи барокко. М., 1979. С. 154-155.

134 Ровинский П. А. Белград, его устройство и общественная жизнь. II. ... С. 75.

135 Подробнее см.: Angyal E. Swiat slowian'skiego baroku (перевод с венгерского оригинала на польский язык). Warszawa, 1972. S. 327-331.

136 Вольский Ст. Письма с Балкан // Русские о Сербии и сербах. Т. I. С. 538. 
137 Ключевский В. О. Афоризмы. Исторические портреты и этюды. Дневники. М., 1993. С. 67.

138 Чириков E. H. Поездка на Балканы. Заметки военного корреспондента. М., 1913. С. 23, 28.

139 Цит. по: Лафан Р. Срби - чувари капије. Приредио Д. Батаковић. Београд, 1994. C. 275.

\section{Резиме}

Др Андреј Шемјакин

\section{Србија и Срби уочи балканских ратова у руским путописима (Прилог дискусији о „модерној“ држави)}

Кључне речи: балкански ратови, медернизација, менталитет српског друштва, политичка култура, национални консензус, Никола Пашић, руски путници

Овим чланком се аутор упушта у дијалог са српским историчарима који сматрају да је после промене династије 1903. године у Србији дошло до „преласка са елитног типа национализма на масовни“, који је постао ослонац националног јединства уочи балканских ратова. „Масовни национализам“ је, као што је познато, категорија модерног друштва. Зато, имајући у виду традиционалну структуру српског друштва, специфичност његовог менталитета и карактерне особине политичке културе елите и становништва, аутор закључује да се национални консензус у Србији формирао на чисто традиционалним и патријархалним (а не модерним) основама. 